\section{THRUSH IN THE NEWBORN}

BY

\section{H. SHRAND, M.B., Ch.B., M.R.C.P.Ed., D.C.H.}

From the Department of Paediatrics and the Institute of Obstetrics and Gynaecology, Queen Charlotte's Maternity Hospital, London

Candida albicans is often found as a saprophyte in the adult mouth, yet whenever these yeast-like fungi are isolated from the mouth of the newborn baby clinical thrush is either present or will become apparent in four or five days (Anderson et al., 1944 ; Harris et al., 1958; Kozinn et al., 1958).

The variations in the reported incidence of oral thrush (Table I) may depend on the following factors: (1) Adequacy of treatment of monilial vulvovaginitis in the mother (see below). (2) Early discharge of babies from hospital, very few cases being detected before the seventh day (see below). (3) Thoroughness of daily examination of the baby's mouth.

TABLE I.-Reported Incidence of Oral Thrush in the Newborn

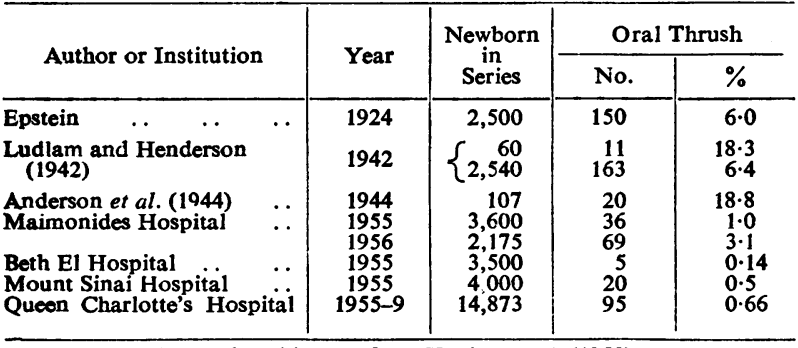

Reproduced in part from Kozinn et al. (1958).

\section{Clinical Thrush in the Newborn}

In the milder cases a few white patches appear on the buccal mucous membrane or tongue which, unlike milk curds, cannot be removed by gentle swabbing. In the more severe case the entire lining of the mouth appears as if heavily frosted and the infant becomes irritable, refusing feeds and losing weight. If the lesion extends to the pharynx and oesophagus, an event fortunately uncommon (Ebbs, 1938; Lederer and Todd, 1949 ; Dobias, 1955 ; Drouhet, 1955 ; Wolff et al., 1955), an apparent incoordination of the swallowing mechanism occurs, with regurgitation of blood-stained vomitus, aspiration pneumonia, and usually death.

Serious septicaemia may occur with involvement of kidneys and meninges (Ludlam and Henderson, 1942 ; Lederer and Todd, 1949 ; Wolff et al., 1955). Most of these infants have received prolonged antibiotic therapy. Wolff et al. (1955) record recoveries after the use of intravenous hydroxystilbamidine, while Drouhet (1958) successfully used oral nystatin in doses up to 2 million units a day for an infant.

The fungus may pass through the bowel with or without diarrhoea, to appear as perianal thrush. Taschdjian and Kozinn (1957) found C. albicans invariably in the stools of those who carried the organism in the mouth ; of these, $50 \%$ developed clinical perianal thrush. Ammoniacal dermatitis, which affects mainly the convexities of the buttocks, must be distinguished from thrush, which usually starts at the perianal margin, spreading outwards with an irregular wetblotting-paper-like fringe with peripheral satellite patches.
Bodian (1958) describes four necropsies on newborn infants where thrush was found and was thought to be an index of debility associated with a malformation or prematurity, but not a cause of death. Lederer and Todd (1949) thought that fatal thrush might be undetected on account of diagnostic difficulties both in life and after death. Oral thrush, although not usually serious, is not innocuous and may lead to an overwhelming infection. Ten deaths due to thrush during the newborn period were registered in England from 1952 to 1957 (Corkindale, 1960). Untreated oral thrush may resolve in about 30 days (Kozinn et al., 1958) ; treated. in about 30 hours. The presence of oral thrush is a potential threat to the infant, and all cases should be treated when diagnosed.

\section{Present Study}

This study correlates the presence of thrush in the newborn with monilial vulvovaginitis in the mother Various factors claimed to predispose to thrush were also investigated.

All the women attending the antenatal departmen during the five-year period 1955-9 who complained of soreness and pruritus with or without obvious discharge, and who were found to be harbouring $C$. albicans in the vagina, were included in this series. Each day the infant's mouth was examined for suspicious patches, and all those from whom $C$. albicans was isolated form the newborn section of this series.

During this period there were 14,873 live births, of whom $1,106(7.3 \%)$ were premature. Monilial vulvovaginitis was found in 232 of the mothers at some time during their pregnancy (Table II)-that is, an incidence of $1.5 \%$ of live births. Oral thrush developed in 95 babies. The correlation of maternal vulvovaginitis treated or untreated, with the incidence of thrush in their offspring, is recorded in Table III.

TABLE II.-Time when Monilial Vulvovaginitis Diagnosed

\begin{tabular}{ll|c|c|c|c|c}
\hline Week ... &.. & $0-12$ & $13-20$ & $21-28$ & $29-36$ & $37-40$ \\
Percentage &. & 2 & 13 & $\begin{array}{c}34 \\
43\end{array}$ & \begin{tabular}{c}
18 \\
\hline
\end{tabular} \\
\hline
\end{tabular}

TABLE III.-Correlation of Maternal Monilial Vulvovaginitis with: Oral Thrush in the Newborn

\begin{tabular}{|c|c|c|c|c|}
\hline \multicolumn{3}{|c|}{ Antenatal Status of Mother } & \multicolumn{2}{|c|}{ Newborns with Thrush } \\
\hline $\begin{array}{c}\text { Monilial } \\
\text { Vulvovaginitis }\end{array}$ & Treatment & $\begin{array}{l}\text { No. of } \\
\text { Cases }\end{array}$ & $\begin{array}{l}\text { No. of } \\
\text { Cases }\end{array}$ & Percentage \\
\hline 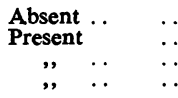 & $\begin{array}{l}\text { Nil } \\
\text { Adequate } \\
\text { Inadequate* } \\
\text { Nil }\end{array}$ & $\begin{array}{r}14,641 \\
210 \\
13 \\
9\end{array}$ & $\begin{array}{r}75 \\
5 \\
8 \\
7\end{array}$ & $\begin{array}{l}0 \cdot 5 \\
20 \\
77\end{array}$ \\
\hline
\end{tabular}

* Inadequate treatment implies the persistence of the illness before the birth of the baby and/or the detection of C. albicans during the puerperiun.

\section{Treatment of Monilial Vulvovaginitis}

Nystatin vaginal tablets $(100,000$ units) inserted twice daily for at least two weeks will cure most cases. Occasionally a patient may require even more prolonged treatment. Decreasing the duration of therapy leads to an increase in failures and relapses (Abbas, 1958; Donald, 1958 ; Jennison, 1958) and a probable increase in the number of infants who will develop oral thrush.

Table IV records the varied treatments used in this series. In some cases more than one preparation was needed.

Table $\mathrm{V}$ notes the details of treatment given to 13 mothers whose infants developed thrush. In Cases 1-8 
the treatment was inadequate, and the discharge either persisted or $C$. albicans was found in the vagina during the puerperium. These cases were not treated for long enough, or may have relapsed. Cases 10-12 were treated adequately, but a bacteriological relapse may have occurred later in pregnancy.

TABLE IV.-Treatments for Monilial Vulvovaginitis Used in this Series

\begin{tabular}{|c|c|c|c|}
\hline \multicolumn{2}{|l|}{ Preparation } & No. of Cases & Percentage \\
\hline 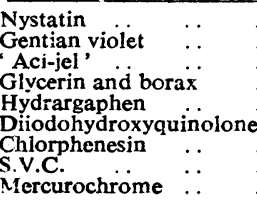 & $\begin{array}{ll}\ldots & \ldots \\
\cdots & \cdots \\
\cdots & \cdots \\
\cdots & \cdots \\
\cdots & \cdots \\
\ldots & \cdots \\
\ldots & \cdots \\
\cdots & \cdots\end{array}$ & $\begin{array}{r}69 \\
50 \\
34 \\
34 \\
15 \\
10 \\
9 \\
4 \\
2\end{array}$ & $\begin{array}{l}30 \\
22 \\
15 \\
15 \\
7 \\
4 \cdot 5 \\
3 \cdot 5 \\
2 \\
1\end{array}$ \\
\hline & & 227 & $100 \%$ \\
\hline
\end{tabular}

TABLE V.-Details of Treatment Given to Mothers with Vaginal Moniliasis whose Babies Developed Thrush

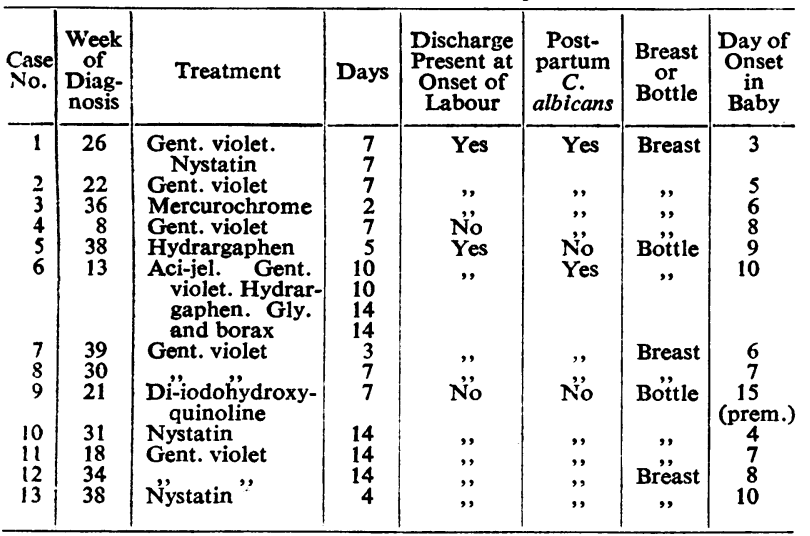

At every antenatal visit direct questioning regarding the presence of vulval itching and discharge should alert the practitioner to the possibility of moniliasis. After mycological confirmation, adequate therapy should be advised. If the illness was first detected early in pregnancy, and adequately treated, a relapse may still occur, and this should be looked for at about the 36th week.

Untreated monilial vulvovaginitis appears to be associated with a higher incidence of thrush in the newborn than when adequately treated. The lowest incidence is found in mothers who have no clinical evidence of infection. In this series (Table III) 14,641 pregnant women with no antepartum history of vaginal moniliasis produced 75 infants who developed thrush, an incidence of $0.5 \%$. Yet nine women with untreated vaginal moniliasis produced seven infants who developed oral thrush-an incidence of $77 \%$. The 210 women with moniliasis " adequately" treated produced but five infants with oral thrush-that is, $2 \%$-and this figure might have been further reduced by more prolonged or repeated treatment later in pregnancy in some of these patients. Thirteen infants developed thrush when the mothers had been treated for monilial vulvovaginitis, and in $8(60 \%)$ the treatment was obviously inadequate-in another 3 probably inadequate.

Bret and Coupe (1958) could not isolate the organism from any newborn when the organism was not found in the mother's vagina during pregnancy. Harris et al. (1958), investigating 1,442 pregnant women, found C. albicans in 254 during early labour. In this group $20 \%$ of their infants harboured C. albicans in the mouth and over half developed clinical thrush. In the group where the organism could not be found, only $1 \%$ of their infants developed thrush.

Dawkins et al. (1958) found C. albicans in the vagina in $7 \%$ of non-pregnant women, $20 \%$ of pregnant women, and only $3 \%$ during the puerperium. This apparently spontaneous cure after delivery may explain those cases where thrush is found in the newborn although the organism cannot be isolated from the mother after the birth of the baby.

Newborn thrush is found more often when the mother harbours the organism during early labour (Harris et al., 1958) or even more so when frank monilial vulvovaginitis is present (Kozinn et al., 1958).

Although Dawkins et al. (1958) found C. albicans in $20 \%$ of their pregnant patients, at the 16 th or 28 th or 32 nd week, in only $8.3 \%$ was there a positive culture on all three occasions. In only one case was oral thrush found in the baby-in this mother $C$. albicans was found on all three occasions. Thus the later $C$. albicans is found during pregnancy the more likely is it to influence the incidence of oral thrush in the newborn.

These yeast-like fungi are seldom isolated from the atmosphere, and all infections appear to have an endogenous source (Conant et al., 1954; Van Breusegham, 1958).

The present concept that most infants are inoculated in transit through the contaminated vagina is confirmed by this series. But the vagina is not the only source (see Table VI).

Browne (1950) states that in maternity hospital nurseries thrush is endemic and every outbreak should be investigated, as the infection is readily conveyed by nurses' hands, utensils, milk, and other means. Bound (1958), discussing perianal moniliasis which often developed after the baby had been taken home, could find oral thrush in but one-third of his cases and suggested that the infection may have been transferred by the mother's contaminated hands when changing napkins.

Table VI.-Possible Source of Infection

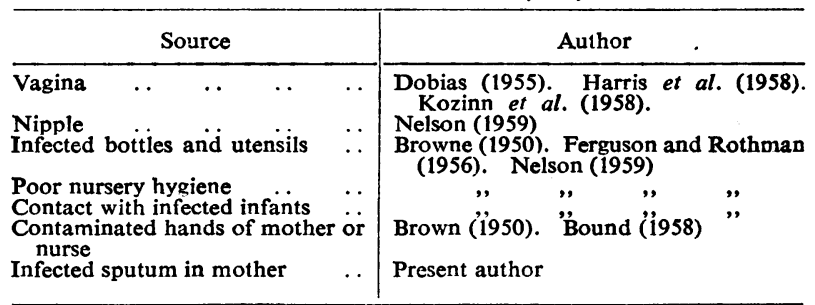

\begin{tabular}{|c|c|c|c|c|c|}
\hline $\begin{array}{l}\text { Case } \\
\text { No. }\end{array}$ & $\begin{array}{l}\text { Vulvo- } \\
\text { vaginitis }\end{array}$ & $\begin{array}{l}\text { Mem- } \\
\text { branes } \\
\text { Rup- } \\
\text { tured }\end{array}$ & $\begin{array}{c}C . \\
\text { albicans } \\
\text { Post- } \\
\text { partum }\end{array}$ & $\begin{array}{l}\text { Breast } \\
\text { or } \\
\text { Bottle }\end{array}$ & $\begin{array}{l}\text { Source } \\
\text { of Infection }\end{array}$ \\
\hline 1 & No & No & $\begin{array}{c}\text { Nega- } \\
\text { tive }\end{array}$ & Breast & $\begin{array}{l}\text { Not found in mother's } \\
\text { mouth, nipple or }\end{array}$ \\
\hline 2 & ," & $30 \mathrm{~min}$. & " & " & $\begin{array}{l}\text { Mother a chronic } \\
\text { bronchitic on } \\
\text { antibiotics through- } \\
\text { out pregnancy. C. } \\
\text { albicans in sputum }\end{array}$ \\
\hline 3 & , , & No & ," & , & $\begin{array}{l}\text { Not found. Mother } \\
\text { had monilial der- } \\
\text { matitis two years }\end{array}$ \\
\hline 4 & $\begin{array}{l}\text { Yes. Emergency } \\
\text { admission. } \\
\text { Gent. violet } \\
\text { paint to vagina } \\
\text { for } 3 \text { days }\end{array}$ & 19 hours & $\begin{array}{c}\text { Posi- } \\
\text { tive }\end{array}$ & Bottle & $\begin{array}{l}\text { ? Ascending infection. } \\
\text { ? Contamination of } \\
\text { mother's hands }\end{array}$ \\
\hline 5 & $\begin{array}{l}\text { Yes. Emergency } \\
\text { admission }\end{array}$ & 19 , & $"$ & ", & $"$ \\
\hline
\end{tabular}


Most recent authors favour the vaginal source of infection and regard hospital contamination as being responsible for relatively few cases of thrush (Bret and Coupé, 1958 ; Harris et al., 1958 ; Kozinn et al., 1958).

In one large series-that of Kozinn-no infant born by caesarean section developed thrush, and this enhanced the idea that all cases of thrush in the newborn developed after passage through the infected vagina. In this series, however, there are five cases of newborn thrush in which delivery was by caesarean section. Details are given in Table VII.

\section{Predisposing Causes}

It is not quite clear why $C$. albicans is usually pathogenic in the mouth of the newborn. Normally multiplication of these organisms is held in check by the natural defence mechanisms of the body, and various authors have suggested that the following host-factors may increase the newborn's susceptibility to oral thrush (Winner, 1958): (1) prematurity ; (2) debility ; (3) diabetes: (4) antibiotic therapy; (5) steroid therapy; (6) local trauma to the baby's mouth during aspiration or resuscitation ; and (7) $p H$ of the newborn's mouth.

Prematurity.-Harris et al. (1958) found that $20 \%$ of his group of 34 infants with oral thrush were premature, whereas the incidence of prematurity in the entire group was only 5\%. Kozinn et al. (1958) could find no more cases among the prematures than among the full-term. Eighty-seven of our cases weighed over $5 \mathrm{lb} .8 \mathrm{oz}$. $(2,500$ g.), leaving eight as prematures-that is, oral thrush developed in $0.64 \%$ of mature babies and $0.7 \%$ of premature babies. Prematurity per se does not seem to be a predisposing factor. Boys and girls were equally affected, and no seasonal incidence could be found for the onset of thrush in either mother or baby.

Antibiotics.-During this period approximately 700 infants were given antibiotics-only four of these developed thrush. Antibiotics did not appear to predispose the newborn to thrush during the first 10 days as only 4 of the 95 who developed thrush had received any antibiotics. Neither breast- nor bottle-feeding favoured the development of oral thrush in the newborn (see Table VIII).

TABLE VIII.-Effect of Feeding on Incidence of Thrush in Newborn

\begin{tabular}{cccc|c|c}
\hline \multicolumn{3}{c|}{ Type of Feeding } & & Babies with Thrush & Unaffected Babies \\
\cline { 3 - 4 } Breast &. &. &.. & $64 \%$ & $70 \%$ \\
Bottle & $\because$ &. &.. & $22 \%$ & $20 \%$ \\
Mixed &. &. & $\cdots$ & $14 \%$ & $10 \%$ \\
\hline
\end{tabular}

TABLE IX.-Age when Thrush Detected in the Newborn

\begin{tabular}{|c|c|c|c|c|c|}
\hline $\begin{array}{l}\text { Day } \\
\text { No. of cases }\end{array}$ & $\frac{0-3}{2}$ & $\begin{array}{l}4-6 \\
10\end{array}$ & $\begin{array}{c}7-10 \\
72\end{array}$ & $\underset{9}{11-14}$ & Over 14 \\
\hline
\end{tabular}

Faulty hygiene and contaminated milk do not seem important as a source of infection in this series.

Thrush was usually detected at the end of the first week, most cases becoming apparent by the seventh day (see Table IX).

$\mathrm{pH}$ of Mouth of the Newborn.-The increased incidence of monilial vulvovaginitis is attributed in part to increased acidity of the vagina during pregnancy (Donald, 1958). The $p H$ of the mouth of 30 infants was tested throughout the first 10 days of life and the majority revealed a $p H$ of 7-8. One case developed thrush, but the $p \mathrm{H}$ was unaltered. Neither breast- nor bottle-feeding had any obvious effect on the $p H$.

Trauma.-It was difficult to assess the influence of trauma to the oral mucosa on the development of thrush. If anything, the babies with thrush had required less resuscitation than the unaffected infants; thus trauma per se does not seem to be an important factor.

\section{Treatment of Oral Thrush in the Newborn}

Almost all cases have responded to either topical gentian violet (aq. solution 0.5 ) or nystatin suspension $(100,000$ units per ml.) four or five times a day until the mouth was clear, plus an extra two days to prevent a relapse (Table $\mathbf{X}$ ).

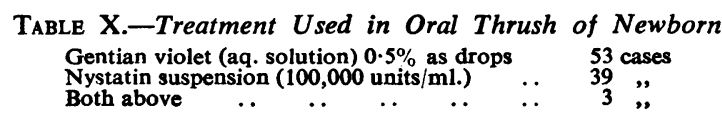

Gentian violet is a cheap satisfactory treatment in most cases, and is best dispensed in a dropper-bottle with instructions to apply three or four drops under the tongue after feeds. The baby's moving tongue will then paint the mouth. This is more effective, quicker, and less messy than trying to paint the patches with a cottonwool swab soaked in gentian violet solution. In two cases thrush did not respond to gentian violet but disappeared when nystatin was used. In one case there was no improvement with nystatin but rapid response to gentian violet. Probably gentian violet should be tried first, keeping nystatin for resistant cases. This may also prevent the emergence of nystatin-resistant strains.

\section{Complications}

During this period of investigation two cases of perianal thrush were detected in the neonatal period and one case of diarrhoea which responded to oral gentian violet.

\section{Discussion}

Prematurity, method of feeding, $p H$ of the baby's mouth, trauma, or antibiotics during the neonatal period do not appear to predispose the baby to oral thrush. Untreated vaginal moniliasis will produce a high incidence of affected infants, whereas adequately treated mothers have a very much lower incidence of thrush in their offspring. It would appear that thrush in the newborn could be prevented in most cases by controlling maternal vaginal moniliasis. Should the mother require to be treated early in pregnancy, a possible relapse should be looked for later. Because $C$. albicans is so often found as a commensal in the vagina and the post-partum cure rate is so high, it is doubtful whether routine search for $C$. albicans and subsequent treatment of the "positive" cases is justifiable. Dawkins et al. (1958) found only one case of thrush in their series of 250 women.

Although the vagina is the most likely source of infection, there are others, and an infant born by caesarean section may develop thrush. The organism may pass from the mother's mouth or hands to the baby, but these routes are uncommon and can be avoided by routine post-partum hygiene.

Whether the baby gets thrush from the nipple or vice versa is difficult to decide, although one case of nipple thrush was eradicated by treating the baby's mouth. 
Daily inspection of the infant's mouth by the mother or nurse, with mycological confirmation of suspicious patches and immediate treatment, will probably control all cases. The daily routine swabbing of infant's mouth for $C$. albicans, and treating when found, or the routine use of prophylactic nystatin has proved successful (Harris et al., 1958 ; Larroche, 1957, quoted by Drouhet, 1958), but it is doubtful whether such measures are necessary. No great harm will ensue if the lesion is missed for a day or two. The microscope and medication should complement and not replace the clinician. (Again, we may produce a resistant strain by these techniques.)

\section{Summary}

The incidence of thrush in the offspring of mothers with untreated monilial vulvovaginitis is very high, decreasing towards zero as the treatment becomes more adequate. Prematurity, breast- or bottle-feeding, antibiotics, or $p H$ of the baby's mouth are not predisposing factors. The vaginal route of infection appears to be the most common. Early clinical detection of infected mothers and infants, and treatment with gentian violet or nystatin will control the disease.

I thank Professor J. H. M. Pinkerton and Dr. A. White Franklin for their encouragement and advice; the pathological department, the records department, and the nursing staff of Queen Charlotte's Maternity Hospital for their help during this study; and the secretarial staff of the Institute of Obstetrics and Gynaecology for their assistance in the preparation of the paper.

\section{REFERENCES}

Abbas, T. M. (1958), J. Obstet, Gynaec., 65, 430.

Anderson, N. A. Sage, D. N. and Spaulding, E. H. (1944). Amer $J$ Dis. Child. 67, 450.

Bodian, M. (1958). In Fungous Diseases and Their Treatment, edited by R. W. Riddell and G. T. Stewart, p. 105. Butterworth, London.

Bound, J. P. (1958). Ibid., p. 102

Bret, J., and Coupé, C. (1958). Presse méd., 66, 937. (Quoted in Paediatric 1959-60 Year Book)

Browne, F. J. (1950). Postgraduate Obstetrics and Gynaecology, p. 148. Butterworths, London.

Corkindale, I. C. J. (1960). General Register Office. (Personal communication.)

Conant, N. F. et al. (1954). Manual of Clinical Mycology, 2nd ed. Saunders, London.

Dawkins, S. M., Edwards, J. M. B., and Clayton, Y. M. (1958) In Fungous Diseases and Their Treatment, edited by $\mathrm{R}$. W. Riddell and G. T. Stewart, p. 94 . Butterworths, London.

Dobias, B. (1955). In Therapy of Fungus Diseases, edited by T. H. Sternberg and V. D. Newcomer.

Donald, I. (1958). In Fungous Diseases and Their Treatment, edited by R. W. Riddell and G. T. Stewart, p. 88. Butterworths, London.

Drouhet, E. (1955). In Therapy of Fungus Disease, edited by T. H. Sternberg and V. D. Newcomer

- (1958). In Fungous Diseases and Their Treatment, edited by R. W. Riddell and G. T. Stewart, p. 192. Butterworths, London.

Ebbs, J. H. (1938). Arch Dis. Childh., 13, 211

Ferguson, E. H., and Rothman, S. (1956). Pediat. Clin. $N$ Amer., 3, 555 .

Harris, L. J., Pritzker, H. G., Laski, B., Eisen, A., Steiner, J. W. and Shack, L. (1958). "Canad. med Ass. J., 79, 891

Jennison, R. F. (1958). In Fungous Diseases and Their Treatment, edited by R. W. Riddell and G. T. Stewart, p. 221. Butterworths, London.

Kozinn, P. J., Taschdjian, C. L., Wiener, H., Dragutsky, D., and Minsky, A. (1958). Pediat. Clin. N. Amer., 5, 803.

Lederer, H., and Todd, R. M. (1949). Arch. Dis. Childh., 24 200 .

Ludlam, G. B. and Henderson, J. L. (1942). Lancet, 1, 64

Nelson, W. E. (1959). Textbook of Paediatrics, 7th ed. Saunders, London.

Taschdjian, C. L., and Kozinn, P. J. (1957). J. Pediat., 50, 426

Van Breusegham, R. (1958). Mycosis of Man and Animal. London.

Winner, H. I. (1958). In Fungous Diseases and Their Treatment. edited by R. W. Riddell and G. T. Stewart, p. 75. Butterworths, London

Wolff, O. H., Petty, B. W., Astley, R., and Smellie, J. M. (1955). Lancet, 1, 991 .

\section{SCLEREMA NEONATORUM TREATED WITH CORTICOSTEROIDS}

\author{
BY
}

SOLOMON E. LEVIN, M.B., B.Ch., M.R.C.P.Ed.

D.C.H.

\section{M. BAKST, M.B., B.Ch.}

AND

\section{ISSEROW, M.B., B.Ch., D.C.H.}

Department of Paediatrics, Baragwanath Hospital, and University of the Witwatersrand, Johannesburg

Before 1948 the survival rate for sclerema neonatorum was about $25 \%$ (Hughes and Hammond, 1948). Infants who recovered were full-term .with birth weights of over $5 \frac{1}{2} \mathrm{lb}$. $(2,500 \mathrm{~g}$.$) . Since then case reports have appeared$ of patients treated with A.C.T.H. and corticosteroids. We have been able to trace 17 infants in the English medical literature who have received these hormones for the treatment of sclerema neonatorum, and 16 of them survived-some of them being premature. The greatest number of cases in any given series was four (Kendig and Toone, 1951; Kendall and Ledis, 1952; Glynn Williams, 1953 ; Kurzrok, Marshall, and Becker, 1954 ; Eisenoff, Aaron, and Green, 1954 ; McDonald, 1955 ; Buess, 1955 ; Davis, 1955 ; Wickes, 1956). So far as we are aware no statistically valid series has been published in which the value of corticosteroids in the treatment of sclerema neonatorum has been assessed.

We are fortunately placed for assessing the value of corticosteroids in this condition, because cold injury in the newborn infant is of common occurrence in the African population served by this hospital. This is particularly so in premature infants, of whom 635 were admitted during 1959, most of them less than $4 \frac{1}{2} \mathrm{lb}$. $(2,040$ g.) in weight. In this paper we compare the results of treatment of sclerema neonatorum with and without corticosteroids.

\section{Material and Methods}

During a nine-month period in 1959 we were able to collect 25 neonates with sclerema neonatorum who were admitted to the lying-in wards, the premature-baby unit, or the paediatric wards of Baragwanath Hospital. The diagnosis was made by at least two of us, and we were guided by Hughes and Hammond's (1948) definition of this condition-namely, that it is "characterized by a diffuse rapidly spreading, non-oedematous, tallow-like hardening of the subcutaneous tissue of infants in the first weeks of life. The skin in involved areas cannot be picked up and the subcutaneous tissues seem bound down to subjacent muscle and bone." All children in this series had non-pitting induration of the skin and subcutaneous tissues in several of the following sites: cheeks, deltoid and scapular regions, arms, forearms, buttocks, and lower limbs. The sclerema was widespread in all but five cases-that is, three or more sites were extensively involved. Of the five infants with less extensive sclerema, two had involvement of the cheeks alone, one showed sclerema of the lower limbs, one of the cheeks and legs, and one of the forearms, legs, and scapular region.

The general therapeutic measures carried out on all the babies in this series were as follows: (1) warming by means of an electric pad, blankets, and cotton-wool 